\title{
TIGA FAKTOR PENGHAMBAT PENGEMBANGAN BISNIS PADA PEDAGANG MUSLIM DI PASAR IKAN HIAS GUNUNGSARI SURABAYA]]
}

\author{
Amri Kumara \\ Mahasiswa Program Studi S1 Ekonomi Islam - Fakultas Ekonomi dan Bisnis - Universitas \\ Airlangga \\ Email:amrikumara@gmail.com \\ R. Moh. Qudsi Fauzy \\ Departemen Ekonomi Islam - Fakultas Ekonomi dan Bisnis - Universitas Airlangga \\ Email: qudsifauzy1@gmail.com
}

\begin{abstract}
:
This research aims to determine the hindering factors that influence bussiness growth of Moslem vendors at Pasar Ikan Hias Gunungsari Surabaya.

This research used quantitative methods through exploratory factor analysis. Characteristic of the population in this research are Moslem vendors at Pasar Ikan Hias Gunungsari Surabaya that have been active for at least a year. The number of samples at the time required 105 respondents. The sampling technique used is probability sampling. Sampling was done using simple random sampling.

Results of the study indicate that there are three hindering factors that influence bussiness growth on Moslem vendors at Pasar Ikan Hias Gunungsari Surabaya. The three factors are the result of reduction of factor analysis processing. These three factors namely are unpreparedness to compete, lack of motivation, and limited funding.

Suggestions for the government as the managing party of Pasar Ikan Hias Gunungsari Surabaya are holding meetings as a mean of discussion and hearing, encouraging entrepreneurial soul of the vendors, and improving the performance of the Building Society. It is suggested for Moslem vendors to join Moeslem entrepreneur community. Further research may focus on these factors influences toward other variables, such as the supporting factor that influences business growth. Moreover, further studies may also enlarge the scope of the research.
\end{abstract}

Keywords: Hindering factor, business growth, Moslem vendors, unpreparedness to compete, motivation, funding.

\section{PENDAHULUAN}

Sebagian besar pengusaha kecil di Indonesia tumbuh sebagai pengusaha berdasarkan keturunan atau sosialisasi dari lingkungan terdekat (saudara atau tetangga). Dampak yang ditimbulkan adalah bahwa bisnis kecil seringkali hanya dijadikan sekedar sebagai 'tempat bisa hidup'. Sehingga bisa dibayangkan sulit untuk mengharapkan bisnis kecil berkembang untuk bisa melakukan pengembangan bisnis dengan maksimal.

Dalam menjalankan suatu bisnis, tentu para pengusaha mikro maupun kecil menginginkan bisnisnya berkembang, 1] Jurnal ini merupakan bagian dari skripsi Amri Kumara, NIM: 041014048, yang diuji pada 13 Februari 2015 sehingga keinginannya menjadi pengusaha besar yang sukses dapat tercapai. Akan tetapi, apakah nasib pedagang dengan skala mikro yang telah dipindahkan atau direlokasi dari tempatnya berdagang di tempat asalnya akan berkembang menjadi semakin baik atau malah semakin memperburuk kondisi bisnis mereka?

Pada tahun 2010, Pemerintah mengeluarkan kebijakan relokasi perdagangan ikan hias yang ada di jalan tersebut agar dipindahkan ke Pasar Ikan Hias Gunungsari yang memiliki bangunan permanen agar jalan yang dulunya
ra, NIM: 041014048, yang diuji pada 13 Februari 
dipergunakan untuk berjualan ikan hias dapat kembali menjadi fungsi awalnya.

Dari hasil wawancara dan pengamatan langsung ke lapangan, peneliti menemukan banyaknya kios-kios pedagang ikan hias yang tutup atau bangkrut dan hanya dijadikan sebagai gudang penyimpanan, khususnya kios yang berada di lantai dua. Selain itu, peneliti juga menemukan banyak pedagang ikan hias yang bertahan untuk berdagang dengan skala mikro saja. Selanjutnya, peneliti menjumpai beberapa pedagang yang telah mengembangkan bisnisnya. Pedagang tersebut terlihat telah mampu memperluas tempatnya berjualan dengan menyewa lebih dari satu kios, membuka cabang di tempat lain, menjadi supplier perlengkapan hewan peliharaan ke pedagang dan petshop yang berada di dalam maupun di luar Pasar Ikan Hias Gunungsari Surabaya.

Peneliti ingin menitikberatkan pada permasalahan faktor penghambat pengembangan bisnis pada pedagang muslim yang berada di Pasar Ikan Hias Gunungsari.

\section{Rumusan Masalah}

Berdasarkan uraian latar belakang diatas maka dapat dirumuskan pertanyaan yang dijadikan acuan dalam penelitian ini, yaitu "Faktor-faktor apa saja yang menjadi penghambat pengembangan bisnis pada pedagang muslim di Pasar Ikan Hias Gunungsari Surabaya?"

\section{Tujuan Penelitian}

Dari rumusan masalah diatas dapat diketahui bahwa tujuan dari penelitian ini, yaitu untuk mengetahui faktor penghambat pengembangan bisnis pada pedagang muslim di Pasar Ikan Hias Gunungsari Surabaya.

\section{LANDASAN TEORI}

Menurut Syafii dalam Alma dan Priansa, (2009: 243) secara etimologi jual beli dapat diartikan sebagai pertukaran sesuatu dengan sesuatu yang lain. Definisi lainnya yang dikemukakan oleh ulama Hanifiyah yang dikutip oleh Ghazaly, et al (2012: 67), jual beli adalah:

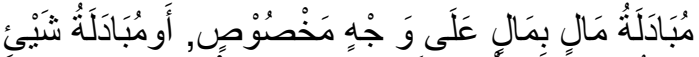

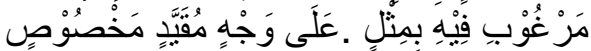

Mubādalatu mālin bimālin 'alā wajhin majșușin, 'awmubādalatu śay'in margūbi fini bimiś 'alā wajhin muqayyadin makhșūșin

Artinya: "Saling tukar harta dengan harta melalui cara tertentu atau tukar menukar sesuatu yang diinginkan dengan yang sepadan melalui cara tertentu yang bermanfaat". (Ghazaly, et al, 2012: 67).

Dalam definisi ini terkandung pengertian "cara tertentu", yang dimaksudkan ulama Hanafiyah dengan kata-kata tersebut adalah ijab dan kabul, atau juga boleh melalui saling memberikan barang dan harga dari penjual dan pembeli. Berikut ini adalah dasar hukum jual beli.

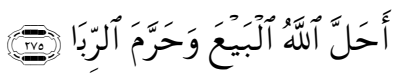

Ahallallahul bay'a waharramaribā 
Artinya: "Allah telah menghalalkan jual beli dan mengharamkan riba..." (DEPAG $\mathrm{Rl}, 2010$ )

Hadis riwayat Rifa'ah ibn Raffi':

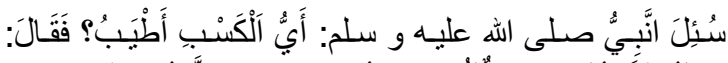

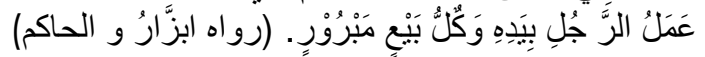

Su'ilinnabiyyu șallallahu 'alayhi wassalam: ayyu alkasbi attyabu? Faqala: 'amalurrajuli biyadihi wakullu bay'in mabrūrin.

Artinya: "Rasulullah SAW ditanya salah seorang sahabat mengenai pekerjaan (profesi) apa yang paling baik. Rasulullah SAW menjawab: Usaha tangan manusia sendiri dan setiap jual beli yang diberkati". (Ghazaly, et al, 2012: 69)

Rasulullah telah menjelaskan melalui hadis diatas bahwa pekerjaan yang paling mulia adalah pekerjaan yang dilakukannya sendiri dan melalui jual beli (perniagaan) yang halal. Manusia dapat memperoleh pekerjaan dibawah pimpinan orang lain maupun menjadi seorang yang mandiri seperti menjadi seorang pengusaha.

\section{Manfaat dan Hikmah Jual Beli}

Adapun manfaat dari jual beli, antara lain (Ghazaly, et al, 2012: 87):

1. Jual beli dapat menata struktur kehidupan ekonomi masyarakat yang menghargai hak milik orang lain.

2. Penjual dan pembeli dapat saling memenuhi kebutuhannya atas dasar kerelaan atau suka sama suka.

3. Jual beli mampu mendorong untuk saling membantu antara penjual dan pembeli dalam kebutuhan sehari-hari.
4. Dapat menjauhkan diri dari memakan atau memiliki barang yang haram (batil).

5. Penjual dan pembeli mendapat rahmat dari Allah SWT.

6. Menumbuhkan ketentraman dan kebahagiaan pada masing-masing pihak.

Hikmah yang terkandung dalam kegiatan jual beli yaitu Allah SWT mensyariatkan jual beli sebagai pemberian keleluasaan hambahambaNya, karena semua manusia secara pribadi mempunyai kebutuhan berupa sandang, papan dan pangan. Tak seorang pun dapat memenuhi hajat hidupnya sendiri, karena itu manusia dituntut untuk berhubungan satu sama lainnya. Dalam hubungan ini yaitu saling tukar menukar, dimana seseorang memberikan sesuatu yang ia miliki untuk kemudian memperoleh sesuatu yang berguna dari orang lain sesuai dengan kebutuhannya masing-masing.

\section{Definisi Bisnis}

Definisi bisnis dalam Kamus Bahasa Indonesia dapat diartikan sebagai usaha dagang, usaha komersial di dunia perdagangan, dan bidang usaha (Poerwadarminta, 1976: 145). Sedangkan menurut pandangan Straub dan Attner, bisnis merupakan suatu organisasi yang menjalankan aktivitas produksi dan penjualan barang-barang dan jasa-jasa yang diinginkan oleh konsumen untuk memperoleh profit. Barang-barang yang dimaksud adalah suatu produk yang 
secara fisik memiliki wujud (dapat diindra), sedangkan jasa merupakan aktivitasaktivitas yang memberi manfaat kepada konsumen atau pelaku bisnis lainnya

\section{Etika Bisnis Islam}

Paradigma bisnis Islam dibangun dan dilandasi oleh aksioma-aksioma berikut (Naqvi, 1993: 86-105):

1. Kesatuan (Tauhid)

Konsep tauhid merupakan dimensi vertikal Islam sekaligus horizontal yang memadukan segi politik, sosial ekonomi kehidupan manusia menjadi sekumpulan yang homogen yang konsisten dari dalam dan luas sekaligus terpadu dengan alam luas.

2. Keseimbangan (equilibrium)

Keseimbangan (equilibrium) atau keadilan menggambarkan dimensi horizontal ajaran Islam yang berhubungan dengan keseluruhan harmoni pada alam semesta. Hukum dan tatanan yang terlihat pada alam semesta mencerminkan keseimbangan yang harmonis. Tatanan ini pula yang dikenal dengan sunnatullah.

3. Kehendak Bebas

Berdasarkan aksioma kehendak bebas ini, dalam bisnis manusia memiliki kebebasan untuk membuat suatu perjanjian termasuk menepati atau mengingkarinya. Seorang muslim yang percaya pada kehendak Allah akan memuliakan semua janji yang dibuatnya (Beekun, 1997: 24-25).

4. Tanggung Jawab

Kebebasan tanpa batas adalah suatu hal yang mustahil dilakukan oleh manusia karena tidak menuntut adanya pertanggungjawaban dan akuntabilitas. Untuk memenuhi tuntutan keadilan dan kesatuan, manusia perlu mempertanggungjawabkan tindakannya (Beekun, 1997: 26).

\section{Pengembangan Bisnis}

Haryadi, et al (1998: 155) menyebutkan ada tiga tahap perkembangan bisnis, yaitu tahap rintisan, tahap berkembang, dan tahap akumulasi modal. Masing-masing tahapan bisnis mempunyai karakteristik dan memperlihatkan dinamikanya yang khas.

Potensi untuk berkembang sangat kuat terlihat pada bisnis kecil tahap berkembang dan akumulasi modal. Bisnis tahap akumulasi modal mempunyai potensi dikenai dampak arus globalisasi ekonomi, dan akan menghadapi persaingan yang semakin ketat, oleh karena itu potensi untuk berkembang dan maju sangat kuat terlihat pada bisnis kecil khususnya tahap akumulasi modal.

\section{Faktor Pendukung Pengembangan Bisnis}

Adapun faktor-faktor pendukung pengembangan bisnis dalam Li (2009: 224), yaitu:

1. Menciptakan atau menambah jaringan bisnis.

2. Menghasilkan pendapatan dan keuntungan yang lebih.

3. Keinginan untuk menguasai persaingan.

4. Bisnisnya telah berjalan dengan baik sehingga tidak ada alasan untuk tidak mengembangkannya. 
Selain itu, menurut Jones (2004: 304) Perkembangan bisnis dipandang sebagai tujuan perusahaan yang sangat penting karena dapat memaksimalkan output. Berikut ini merupakan motivasi dalam mengembangkan bisnis:

1. Meningkatkan keuntungan total.

2. Meningkatkan efisiensi melalui skala ekonomi, ruang lingkup dan pembelajaran.

3. Meningkatkan pangsa pasar dan kekuatan pasar.

4. Mengurangi unit biaya manajemen.

5. Mengurangi biaya transaksi jika pemasok utama dan outlet penjualan telah diperoleh.

6. Mengurangi risiko dan ketidakpastian karena ukuran perusahaan yang lebih besar membuat perusahaan lebih kompetitif, sedangkan diversifikasi ke produk-produk baru mengurangi masalah yang dihadapi oleh penurunan permintaan di pasar utama.

7. Meningkatkan keamanan manajerial terhadap tawaran pengambilalihan yang tidak diinginkan.

Faktor Penghambat Pengembangan Bisnis

Menurut Haryadi, et al (1998: 131-

140), ada beberapa hal yang menghambat seorang pelaku bisnis dalam mengembangkan bisnisnya, yaitu:

1. Keterbatasan modal yang dimiliki.

2. Ilmu pengetahuan dan teknologi yang semakin modern.

3. Enggan dalam mengambil resiko.
4. Pendidikan dan keterampilan yang kurang.

5. Kurangnya motivasi/dorongan kuat untuk berubah menjadi lebih baik.

6. Kurangnya SDM atau tenaga kerja.

7. Hanya ingin mencari peluang pasar terdekat.

8. Kesulitan dalam menyuplai bahan baku.

9. Lembaga pemerintah/non pemerintah tidak berjalan dengan baik.

Selain itu, ada beberapa faktor penghambat perkembangan Usaha Kecil dan Menengah (UKM) yang dikemukakan oleh Hafsah (2004) yang dibagi menjadi faktor internal dan faktor eksternal, antara lain:

1. Faktor Internal

a. Kurangnya Permodalan.

b. Sumber Daya Manusia (SDM) yang terbatas.

c. Lemahnya jaringan usaha dan kemampuan penetrasi pasar.

2. Faktor Eksternal

a. Iklim usaha belum sepenuhnya kondusif.

b. Terbatasnya sarana dan prasarana usaha.

c. Implikasi otonomi daerah.

d. Implikasi perdagangan bebas.

e. Sifat produk dengan lifetime pendek.

f. Terbatasnya akses pasar.

\section{METODE PENELITIAN}

Penelitian ini menggunakan pendekatan kuantitatif eksploratori 
(eksploratif). Malhotra (2009:89-90) mengatakan bahwa riset eksploratif bertujuan untuk mendapatkan gambaran dan pemahaman mengenai masalah yang dihadapi peneliti.

\section{Identifikasi Variabel}

Dalam penelitian yang menggunakan analisis faktor tidak diidentifikasikan variabel bebas maupun variabel terikat. Pada penelitian ini dirumuskan 21 indikator yang akan direduksi menjadi faktor atau variabel. Variabel yang diteliti adalah penghambat pengembangan bisnis pada pedagang muslim di Pasar Ikan Hias Gunungsari Surabaya.

\section{Definisi Operasional Indikator}

Definisi operasional dari variabelvariabel yang dianalisis adalah sebagai berikut:

1. Keterbatasan modal yang dimiliki (X1) adalah pedagang muslim di Pasar Ikan Hias Gunungsari Surabaya tidak memiliki cukup dana yang akan digunakan dalam memenuhi kebutuhan yang diperlukan untuk dapat mengembangkan bisnisnya.

2. Kurang menguasai ilmu pengetahuan dan teknologi yang semakin modern (X2) adalah pedagang muslim di Pasar Ikan Hias Gunungsari Surabaya tidak dapat mengikuti perkembangan ilmu pengetahuan dan penggunaan teknologi yang baru untuk dapat menunjang pengembangan bisnisnya.
3. Enggan dalam mengambil resiko (X3) adalah dimana pedagang muslim di Pasar Ikan Hias Gunungsari Surabaya masih memiliki rasa takut apabila pengembangan bisnis yang akan dilakukan tidak sesuai harapan atau gagal, maka mereka cenderung menghindari resiko tersebut dengan tidak melakukan pengembangan bisnis.

4. Pendidikan dan keterampilan yang kurang (X4) adalah dimana kondisi pedagang muslim di Pasar Ikan Hias Gunungsari Surabaya yang tidak memiliki cukup pengetahuan dan keterampilan yang luas dalam dunia bisnis.

5. Kurangnya motivasi/dorongan kuat untuk merubah bisnisnya menjadi lebih baik (X5) adalah kondisi pedagang muslim di Pasar Ikan Hias Gunungsari Surabaya tidak memiliki motivasi/dorongan dari diri sendiri maupun dari orang lain dalam melakukan suatu pembaharuan menjadi lebih baik yang akan dilakukan pada bisnisnya.

6. Kurangnya SDM atau tenaga kerja (X6) adalah dimana pedagang muslim di Pasar Ikan Hias Gunungsari Surabaya mengalami kesulitan dan membutuhkan sumber daya manusia atau tenaga kerja yang sesuai dengan bidang bisnis yang dijalaninya.

7. Hanya ingin mencari peluang pasar terdekat (X7) adalah suatu kondisi 
dimana pedagang muslim di Pasar Ikan Hias Gunungsari Surabaya hanya ingin melayani konsumen yang ada disekitarnya saja sehingga akan lebih memudahkan transaksi.

8. Kesulitan dalam mendapatkan bahan baku/barang dagangan (X8) adalah mereka pedagang muslim di Pasar Ikan Hias Gunungsari Surabaya yang memiliki kesulitan akses dalam menemukan supplier barang dagangannya dalam jumlah besar apabila bisnisnya telah berkembang dan permintaan meningkat.

9. Bantuan dari lembaga pemerintah/non pemerintah tidak berjalan dengan baik (X9) adalah dimana suatu organisasi pemerintah/non pemerintah sama sekali tidak membantu pengembangan bisnis kecil, atau membantu dan memiliki kontribusi pada bisnis kecil namun manfaatnya belum dapat dirasakan oleh pedagang muslim di Pasar Ikan Hias Gunungsari Surabaya.

10. Lemahnya jaringan bisnis $(\mathrm{X} 10)$ adalah dimana pedagang muslim di Pasar Ikan Hias Gunungsari Surabaya tidak memiliki partner/kerjasama antar pedagang atau komunitas bisnis untuk dimanfaatkan sebagai peluang dalam mengembangkan bisnisnya.

11. Birokrasi dan perijinan yang rumit $(X 11)$ adalah pedagang muslim di Pasar Ikan Hias Gunungsari Surabaya merasa bahwa prosedur dalam mengurus perijinan usaha sangat sulit, membutuhkan biaya dan waktu yang lama sehingga mereka mengurungkan niatnya untuk mengembangkan bisnisnya.

12. Terbatasnya sarana dan prasarana (X12) adalah dimana pedagang muslim di Pasar Ikan Hias Gunungsari Surabaya tidak memiliki sarana dan prasarana, fasilitas serta terbatasnya lokasi bisnis dalam menunjang pengembangan bisnisnya.

13. Penarikan pajak daerah yang terlalu tinggi (X13) adalah dimana pedagang muslim di Pasar Ikan Hias Gunungsari Surabaya merasa pajak yang harus disetorkan ke pemerintah daerah terlalu besar setelah bisnisnya berkembang, sehingga mereka mengurungkan niatnya untuk mengembangkan bisnisnya.

14. Kendala perdagangan bebas (X14) adalah dimana pedagang muslim di Pasar Ikan Hias Gunungsari Surabaya mengalami kesulitan memperdagangkan barang dagangannya, dikarenakan banyaknya barang impor yang memiliki kualitas dan harga yang lebih kompetitif.

15. Barang dagangan yang tidak tahan lama (X15) adalah barang yang dijual oleh pedagang muslim di Pasar Ikan Hias Gunungsari Surabaya merupakan hewan peliharaan, semakin lama dan semakin banyak 
stok yang dipertahankan maka akan semakin banyak biaya yang dikeluarkan, sehingga mereka meminimalisirkan biayanya dengan memilih untuk tidak mengembangkan bisnisnya.

16. Mengalami kesulitan dalam memasarkan barang dagangan (X16) adalah pedagang muslim di Pasar Ikan Hias Gunungsari Surabaya kurang memiliki keahlian komunikasi dan promosi untuk dapat mempersuasi konsumen dan menentukan sasaran yang tepat, sehingga barang yang diperdagangkan tidak dapat terjual dengan mudah.

17. Belum ada niat dalam mengembangkan bisnis yang telah dijalani (X17) adalah suatu kondisi pedagang muslim di Pasar Ikan Hias Gunungsari Surabaya dimana ia belum memiliki pikiran atau niat dalam mengembangkan bisnisnya sehingga bisnisnya bertahan dalam kondisi tersebut.

18. Kondisi bisnis saat ini telah cukup untuk memenuhi kebutuhan hidup (X18) adalah dimana kondisi kevangan pedagang muslim di Pasar Ikan Hias Gunungsari Surabaya yang telah cukup dalam memenuhi kebutuhan hidup pemiliknya, sehingga pemilik merasa tidak perlu melakukan pengembangan bisnis.

19. Takut bisnisnya akan lebih tidak terorganisir (X19) adalah perasaan pedagang muslim di Pasar Ikan Hias Gunungsari Surabaya yang tidak memiliki kepercayaan diri dalam mengelola bisnisnya sehingga takut bisnisnya tidak berjalan dengan baik.

20. Tidak ada orang yang menuntun dalam mengembangkan bisnis (X20) adalah pedagang muslim di Pasar Ikan Hias Gunungsari Surabaya tidak tahu apa yang harus dilakukan ketika memulai untuk mengembangkan bisnisnya, sehingga peran seorang mentor atau yang telah berpengalaman sangat diperlukan.

21. Tidak siap dalam menghadapi persaingan dengan bisnis yang lebih besar (X21) adalah pedagang muslim di Pasar Ikan Hias Gunungsari Surabaya yang memiliki rasa kurang percaya diri untuk bersaing dengan pesaing lainnya yang juga terlebih dahulu mengembangkan bisnisnya.

Indikator-indikator tersebut kemudian akan diteliti lebih lanjut dengan cara menyebarkan kuesioner dengan menggunakan skala Likert yang telah dimodifikasi yaitu terdiri dari, Sangat Setuju (skor 4), Setuju (skor 3), Tidak Setuju (skor 2), Sangat Tidak Setuju (1).

\section{Populasi dan Sampel}

Karakteristik populasi dalam penelitian ini adalah pedagang muslim yang masih aktif berjualan di Pasar Ikan Hias Gunungsari Surabaya minimal selama satu tahun. Pasar Ikan Hias Gunungsari Surabaya memiliki jumlah kios sebanyak 
158 buah, namun tidak semuanya terisi oleh pedagang.

Jumlah sampel dalam analisis faktor paling sedikit harus empat atau lima kali dari jumlah variabel (Malhotra, 2010:291). Dalam penelitian ini didapatkan 21 indikator, dikali dengan 5 maka akan didapat sebanyak 105 responden. Sampel penelitian ini yaitu pedagang muslim yang masih aktif berjualan di Pasar Ikan Hias Gunungsari Surabaya minimal selama satu tahun. Jumlah sampel pada saat preliminary test dengan melakukan wawancara tertulis sebanyak 10 informan.

\section{Metode Pengambilan Sampel}

Teknik pengambilan sampel yang digunakan adalah probability sampling yaitu teknik pengambilan sampel yang memberikan peluang yang sama bagi setiap unsur (anggota) populasi untuk dipilih menjadi anggota sampel (Sugiyono, 2008: 82). Sedangkan dalam penentuan sampel menggunakan metode simple random sampling, yaitu metode yang memberikan kesempatan sama yang bersifat tak terbatas pada setiap elemen populasi untuk dipilih sebagai sampel (Anshori, 2009: 103).

\section{Teknik Analisis}

Teknik analisis data menggunakan analisis faktor eksplarotari, merupakan teknik statistik multivariat yang digunakan untuk menguji hubungan dari variabelvariabel yang memiliki hubungan saling tergantung (interdependensi). Model analisis faktor secara umum sebagai berikut:
$X i=A i l F 1+A i 2 F 2+A i 3 F 3+. .+A i m F m+V i U i$ Dimana:

$\mathrm{Xi}=$ Standarisasi indikator ke-1

Ail = Standarisasi koefisien regresi berganda indikator 1 pada faktor biasa j

F2 = Faktor biasa

$\mathrm{Vi}=$ Standarisasi koefisien regresi dari indikator 1 pada unik i

$\mathrm{Ui}=$ Faktor unik untuk indikator 1

$M=$ Banyaknya faktor biasa

Faktor-faktor yang unik tidak saling berkorelasi dan tidak berkorelasi dengan faktor biasa. Faktor-faktor biasa sendiri dapat dinyatakan sebagai kombinasi linear dari indikator yang diamati. Persamaannya sebagai berikut:

$F i=W i 1 X 1+W i 2 X 2+W i 3 X 3+\ldots+W i k X k$

Keterangan:

$\mathrm{Fi}$ = Estimasi faktor ke-1

Wi = Bobot atau skor koefisien faktor

$\mathrm{K}=$ Jumlah variabel

\section{Uji Validitas dan Reliabilitas}

Kriteria valid adalah bila korelasi $r>0$. Jadi apabila korelasi antara butir dengan skor total $<0,3$ maka butir dalam instrument tersebut dinyatakan valid (Sugiyono, 2010:126). Suatu skala pengukuran disebut valid apabila melakukan apa yang seharusnya dilakukan dan mengukur apa yang seharusnya diukur (Kuncoro, 2003:151).

Sedangkan reliabilitas menurut Nazir (2003:133) adalah alat Ukur mempunyai reliabilitas tinggi atau dapat dipercaya apabila alat ukur itu mantap atau stabil, dapat diandalkan dan dapat 
diramalkan. Keseluruhan indikator dianggap sudah cukup reliabel bilamana $a \geq 0,6$. Pengujian instrument penelitian dilakukan dengan instrumen komputer melalui program SPSS release 17.

\section{Analisis Data}

Teknik analisis data dalam penelitian ini menggunakan teknik analisis faktor eksploratori yang merupakan teknik statistik multivariat yang bertujuan untuk meringkas indikator-indikator ke dalam faktor yang tidak saling berkorelasi. Model atau teknik analisis faktor, menggunakan Principal Component Analysis (PCA). Hasil perhitungan menurut Maholtra (1996: 646) terdapat beberapa kunci statistik, antara lain:

Barlett's test of sphericity, yaitu yang digunakan untuk menguji interdependensi antara butir-butir yang menjadi indikator suatu indikator atau faktor. Analisis ini bermaksud untuk mengetahui indikator yang tidak berkolerasi satu dengan yang lainnya (colinearity) dalam populasi.

Tabel 1.

Kaiser-Meyer Olkin (KMO) Measure of Sampling Adequancy

\begin{tabular}{|c|c|c|}
\hline \hline \multicolumn{2}{|c|}{$\begin{array}{c}\text { Kaiser-Meyer-Olkin Measure of } \\
\text { Sampling Adequacy. }\end{array}$} & 0,905 \\
\hline \multirow{2}{*}{$\begin{array}{c}\text { Bartlett's Test } \\
\text { of Sphericity }\end{array}$} & Approx. Chi-Square & 1469,196 \\
\cline { 2 - 3 } & $\mathrm{df}$ & 210 \\
\cline { 2 - 3 } & Sig. & 0,000 \\
\hline \hline
\end{tabular}

Sumber: Hasil penelitian, 2015 (data diolah)

Nilai KMO ini menunjukkan bahwa $0,905>0,5$, yang berarti bahwa korelasi antar indikator dapat menjelaskan indikator lain dan analisis faktor sesuai untuk dijadikan alat analisis.
Correlation matrix, yaitu matrik korelasi yang merupakan hasil korelasi antar butir yang menunjukkan koefisien korelasi ( $r$ ) antara butir satu dengan butir yang lainnya, yang dapat atau tidak dapat dimasukkan dalam analisis.

Tabel 2.

Nilai Korelasi Anti Image

\begin{tabular}{|c|c|c|}
\hline \hline Indikator & $\begin{array}{c}\text { Nilai Korelasi (anti } \\
\text { image) }\end{array}$ & Keputusan \\
\hline \hline$X_{1}$ & 0,797 & Dapat dianalisis \\
\hline$X_{2}$ & 0,945 & Dapat dianalisis \\
\hline$X_{3}$ & 0,897 & Dapat dianalisis \\
\hline$X_{4}$ & 0,920 & Dapat dianalisis \\
\hline$X_{5}$ & 0,855 & Dapat dianalisis \\
\hline$X_{6}$ & 0,884 & Dapat dianalisis \\
\hline$X_{7}$ & 0,924 & Dapat dianalisis \\
\hline$X_{8}$ & 0,936 & Dapat dianalisis \\
\hline$X_{9}$ & 0,939 & Dapat dianalisis \\
\hline$X_{10}$ & 0,892 & Dapat dianalisis \\
\hline$X_{11}$ & 0,937 & Dapat dianalisis \\
\hline$X_{12}$ & 0,877 & Dapat dianalisis \\
\hline$X_{13}$ & 0,823 & Dapat dianalisis \\
\hline$X_{14}$ & 0,870 & Dapat dianalisis \\
\hline$X_{15}$ & 0,915 & Dapat dianalisis \\
\hline$X_{16}$ & 0,888 & Dapat dianalisis \\
\hline$X_{17}$ & 0,879 & Dapat dianalisis \\
\hline$X_{18}$ & 0,911 & Dapat dianalisis \\
\hline$X_{19}$ & 0,926 & Dapat dianalisis \\
\hline$X_{20}$ & 0,925 & Dapat dianalisis \\
\hline$X_{21}$ & 0,912 & dianalisis \\
\hline \hline$x_{1}$ & $0,197,2015$ & dialat) \\
\hline
\end{tabular}

Sumber: Hasil penelitian, 2015 (data diolah)

Hasil perhitungan menunjukkan bahwa anti image correlation seluruh indikator sudah bernilai lebih dari 0,5 sehingga dapat dilanjutkan pada analisis berikutnya. Communality, yaitu jumlah varians yang diberikan tiap-tiap butir dalam butir lain. Koefisien communality $50 \%$, maka harus dipertimbangkan besarnya muatan faktor.

Tabel 3.

Nilai Communalities

\begin{tabular}{|c|c|}
\hline \hline Indikator & Extraction \\
\hline \hline$X_{1}$ & 0,727 \\
\hline$X_{2}$ & 0,544 \\
\hline$X_{3}$ & 0,673 \\
\hline$X_{4}$ & 0,774 \\
\hline$X_{5}$ & 0,642 \\
\hline$X_{6}$ & 0,580 \\
\hline
\end{tabular}




\begin{tabular}{|l|l|}
\hline$X_{7}$ & 0,621 \\
\hline$X_{8}$ & 0,638 \\
\hline$X_{9}$ & 0,684 \\
\hline$X_{10}$ & 0,678 \\
\hline$X_{11}$ & 0,650 \\
\hline$X_{12}$ & 0,615 \\
\hline$X_{13}$ & 0,393 \\
\hline$X_{14}$ & 0,546 \\
\hline$X_{15}$ & 0,437 \\
\hline$X_{16}$ & 0,733 \\
\hline$X_{17}$ & 0,641 \\
\hline$X_{18}$ & 0,474 \\
\hline$X_{19}$ & 0,669 \\
\hline$X_{20}$ & 0,621 \\
\hline$X_{21}$ & 0,836 \\
\hline \hline
\end{tabular}

Sumber: Hasil penelitian, 2015 (data diolah)

Hasil perhitungan pada Tabel 3 menunjukkan nilai korelasi tertinggi pada indikator ke-21 dengan nilai 0,836. Sedangkan nilai korelasi terendah 0,393 pada indikator ke-13 yang berarti indikator tersebut berkorelasi paling rendah dengan faktor yang akan terbentuk dan mempunyai nilai kurang dari 0,5.

Faktor yang mempunyai eigenvalue satu, dimasukkan ke dalam model, sedangkan yang nilainya kurang dari satu merupakan faktor yang tidak dimasukkan dalam model. Apabila eigenvalue lebih besar dari satu maka semakin representatif faktor tersebut mewakili indikator.

Tabel 4.

Nilai Eigenvalue dan \% Variance Explained

\begin{tabular}{|c|c|c|c|c|c|c|}
\hline $\begin{array}{l}\mathrm{C} \\
\mathrm{o}\end{array}$ & \multicolumn{3}{|c|}{ Initial Eigenvalues } & \multicolumn{3}{|c|}{$\begin{array}{c}\text { Rotation Sums of Squared } \\
\text { Loadings }\end{array}$} \\
\hline $\begin{array}{l}m \\
p\end{array}$ & Total & $\begin{array}{l}\% \text { of } \\
\text { Var. }\end{array}$ & $\underset{\%}{\text { Cum. }}$ & Total & $\begin{array}{l}\% \text { of } \\
\text { Var. }\end{array}$ & $\underset{\%}{\text { Cum. }}$ \\
\hline 1 & 9,951 & 47,385 & 47,385 & 5,566 & 26,506 & 26,506 \\
\hline 2 & 1,911 & 9,101 & 56,486 & 4,854 & 23,116 & 49,622 \\
\hline 3 & 1,316 & 6,266 & 62,752 & 2,757 & 13,130 & 62,752 \\
\hline
\end{tabular}

Sumber: Hasil penelitian, 2015 (data diolah)

Hasil penelitian pada Tabel 4.8 menunjukkan komponen faktor yang terbentuk ada tiga. Ini menunjukkan ada tiga faktor yang terbentuk dari hasil rotasi faktor. Komponen faktor berhenti pada nilai eigenvalue sebesar 1,316.

Percentage of variance, yaitu total dari varians explained atribut-atribut dari masing-masing faktor sebesar $62,752 \%$. Nilai ini lebih dari 50\% sehingga faktor yang terbentuk dari proses analisis faktor dapat diterima.

Tabel 5.

Hasil Perhitungan Rotasi Faktor

\begin{tabular}{|c|c|c|c|}
\hline \hline \multirow{2}{*}{ Indikator } & \multicolumn{3}{|c|}{ Component } \\
\cline { 2 - 4 } & $\mathbf{1}$ & $\mathbf{2}$ & $\mathbf{3}$ \\
\hline \hline $\mathrm{X}_{1}$ & 0,020 & $-0,037$ & $\mathbf{0 , 8 5 2}$ \\
\hline $\mathrm{X}_{2}$ & 0,185 & $\mathbf{0 , 5 5 2}$ & 0,454 \\
\hline $\mathrm{X}_{3}$ & 0,406 & 0,445 & $\mathbf{0 , 5 5 7}$ \\
\hline $\mathrm{X}_{4}$ & 0,289 & $\mathbf{0 , 6 5 2}$ & 0,515 \\
\hline $\mathrm{X}_{5}$ & 0,185 & $\mathbf{0 , 7 5 5}$ & $-0,194$ \\
\hline $\mathrm{X}_{6}$ & 0,384 & $\mathbf{0 , 6 4 0}$ & 0,152 \\
\hline $\mathrm{X}_{7}$ & 0,292 & 0,491 & $\mathbf{0 , 5 4 2}$ \\
\hline $\mathrm{X}_{8}$ & 0,472 & $\mathbf{0 , 6 0 8}$ & 0,213 \\
\hline $\mathrm{X}_{9}$ & 0,373 & 0,377 & $\mathbf{0 , 6 3 4}$ \\
\hline $\mathrm{X}_{10}$ & 0,191 & $\mathbf{0 , 7 4 0}$ & 0,308 \\
\hline $\mathrm{X}_{11}$ & $\mathbf{0 , 6 8 6}$ & 0,356 & 0,231 \\
\hline $\mathrm{X}_{12}$ & 0,272 & $\mathbf{0 , 7 1 9}$ & 0,157 \\
\hline $\mathrm{X}_{13}$ & $\mathbf{0 , 5 5 5}$ & 0,183 & 0,225 \\
\hline $\mathrm{X}_{14}$ & $\mathbf{0 , 7 2 3}$ & 0,088 & 0,124 \\
\hline $\mathrm{X}_{15}$ & 0,103 & $\mathbf{0 , 6 3 3}$ & 0,159 \\
\hline$X_{16}$ & $\mathbf{0 , 8 0 7}$ & 0,263 & 0,115 \\
\hline$X_{17}$ & $\mathbf{0 , 8 0 1}$ & 0,007 & $-0,006$ \\
\hline$X_{18}$ & $\mathbf{0 , 6 3 4}$ & 0,266 & 0,043 \\
\hline$X_{19}$ & $\mathbf{0 , 6 7 8}$ & 0,430 & 0,155 \\
\hline$X_{20}$ & $\mathbf{0 , 6 5 4}$ & 0,320 & 0,303 \\
\hline$X_{21}$ & $\mathbf{0 , 8 0 7}$ & 0,364 & 0,230 \\
\hline \hline
\end{tabular}

Sumber: Hasil penelitian, 2015 (data diolah)

Dalam rotasi faktor yang dapat diinterpretasikan adalah apabila mempunyai nilai loading faktor lebih dari 0,5 .

Faktor pertama yang mempunyai nilai lebih dari 0,5 pada indikator $X_{11}, X_{13}$, $X_{14}, X_{16}, X_{17}, X_{18}, X_{19}, X_{20}$, dan $X_{21}$. Nilai loading faktor tertinggi terletak pada indikator ke-21 $\left(\mathrm{X}_{21}\right)$ dengan nilai loading 0,8068 . Indikator tersebut mengenai ketidaksiapan pedagang muslim di Pasar ikan Hias Gunungsari Surabaya dalam menghadapi persaingan bisnis yang lebih 
besar apabila mereka mengembangkan bisnisnya. Berdasarkan indikator tersebut, maka disebut atau dinamai dengan faktor

\section{ketidaksiapan untuk bersaing.}

Faktor kedua yang mempunyai nilai lebih dari 0,5 pada indikator $X_{2}, X_{4}, X_{5}$, $X_{6}, X_{8}, X_{10}, X_{12}$, dan $X_{15}$. Nilai loading faktor tertinggi terletak pada indikator kelima (X5) dengan nilai loading 0,755. Indikator tersebut mengenai kurangnya motivasi/dorongan pedagang muslim di Pasar ikan Hias Gunungsari Surabaya untuk merubah bisnisnya menjadi lebih baik. Berdasarkan indikator tersebut, maka disebut atau dinamai dengan faktor

\section{kurangnya motivasi.}

Faktor ketiga yang mempunyai nilai lebih dari 0,5 pada indikator $X_{1}, X_{3}, X_{7}$, dan $X_{9}$. Nilai loading faktor tertinggi terletak pada indikator pertama $\left(X_{1}\right)$ dengan nilai loading 0,852. Indikator tersebut mengenai keterbatasan modal yang dimiliki oleh pedagang muslim di Pasar Ikan Hias Gunungsari Surabaya. Berdasarkan indikator tersebut maka disebut atau dinamai dengan faktor

\section{keterbatasan modal.}

Tabel 6.

Hasil Uji Validitas dan Reliabilitas Konfirmasi Hasil Analisis Faktor

\begin{tabular}{|c|c|c|c|c|c|}
\hline Faktor & Indikator & $\begin{array}{l}\text { Corrected } \\
\text { Item-Total } \\
\text { Correlation }\end{array}$ & Ket. & $\begin{array}{c}\text { Alpha } \\
\text { Cronbach }\end{array}$ & Ket. \\
\hline \multirow{9}{*}{$\begin{array}{l}1 \text { (Faktor } \\
\text { ketidaksiapan } \\
\text { untuk } \\
\text { bersaing) }\end{array}$} & $\overline{X_{11}}$ & 0,745 & Valid & \multirow{9}{*}{0,914} & \multirow{9}{*}{ Reliabel } \\
\hline & $X_{13}$ & 0,566 & Valid & & \\
\hline & $X_{14}$ & 0,637 & Valid & & \\
\hline & $X_{16}$ & 0,776 & Valid & & \\
\hline & $x_{17}$ & 0,624 & Valid & & \\
\hline & $X_{18}$ & 0,615 & Valid & & \\
\hline & $\frac{X_{18}}{X_{19}}$ & 0,753 & Valid & & \\
\hline & $X_{20}$ & 0,719 & Valid & & \\
\hline & $X_{21}$ & 0,878 & Valid & & \\
\hline \multirow{8}{*}{$\begin{array}{l}2 \text { (Faktor } \\
\text { kurangnya } \\
\text { motivasi) }\end{array}$} & $\mathrm{X}_{2}$ & 0,609 & Valid & \multirow{8}{*}{0,891} & \multirow{8}{*}{ Reliabel } \\
\hline & $\mathrm{X}_{4}$ & 0,785 & Valid & & \\
\hline & $x_{5}$ & 0,556 & Valid & & \\
\hline & $\frac{x_{6}}{x_{6}}$ & 0,696 & Valid & & \\
\hline & $X_{8}$ & 0,703 & Valid & & \\
\hline & $x_{10}$ & 0,747 & Valid & & \\
\hline & $X_{12}$ & 0,682 & Valid & & \\
\hline & $X_{15}$ & 0,542 & Valid & & \\
\hline \multirow{2}{*}{$\begin{array}{c}3 \text { (Faktor } \\
\text { keterbatasan }\end{array}$} & $\frac{x_{15}}{X_{1}}$ & 0,460 & Valid & \multirow{2}{*}{0,813} & \multirow{2}{*}{ Reliabel } \\
\hline & $\frac{1}{x_{3}}$ & 0,729 & Valid & & \\
\hline
\end{tabular}

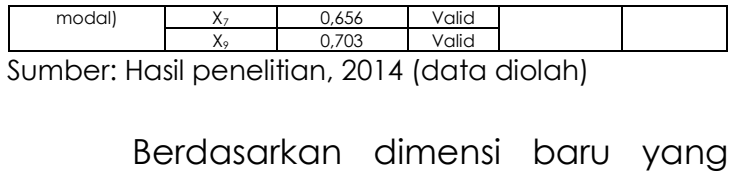

terbentuk setelah dilakukannya exploratory factor analysis maka indikator pernyataan dalam mendeskripsikan faktor yang ada pada penelitian seluruhnya reliabel. Hasil ini menunjukkan bahwa seluruh faktor yang telah terbentuk berpengaruh pada pengembangan bisnis pedagang muslim di Pasar ikan Hias Gunungsari Surabaya.

\section{HASIL DAN PEMBAHASAN}

\section{Faktor Ketidaksiapan untuk Bersaing}

Pedagang muslim merasa bahwa mereka belum siap dalam menghadapi para pesaing-pesaing bisnis yang lebih besar yang telah dulu berkembang, sehingga mereka memilih untuk tidak mengembangkan bisnisnya karena takut kalah oleh pesaingnya. Firman Allah SWT tentang persaingan terdapat pada AlQuran surat Al-Baqarah ayat 148:

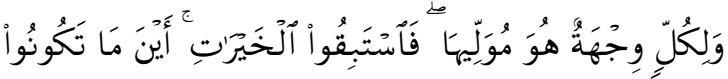

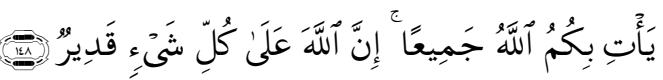

Wali-kullin wij-hatun huwa muwalliha fa'istabiqū al-khayrati 'aynama takunu ya-'ti bikumu Allahu jami'an 'inna Allaha 'ala kulli shay-'in Qadirun

Artinya: "dan bagi tiap-tiap umat ada kiblatnya (sendiri) yang ia menghadap kepadanya. Maka berlomba-lombalah (dalam membuat) kebaikan. di mana saja kamu berada pasti Allah akan mengumpulkan kamu sekalian (pada hari kiamat). Sesungguhnya Allah Maha Kuasa atas segala sesuatu." (DEPAG RI, 2010) 
Fakta di lapangan menunjukkan bahwa pedagang muslim di Pasar Ikan Hias Gunungsari Surabaya tidak memiliki kesiapan untuk bersaing dengan bisnis yang lebih besar karena sebagian besar mereka belum memiliki keberanian untuk memulai mengembangkan bisnisnya, sebagian lainnya menyampaikan bahwa tidak adanya orang atau lembaga tertentu yang memberikan tuntunan atau bimbingan dalam memulai mengembangkan bisnis, sehingga mereka merasa khawatir atau takut salah langkah dalam memasuki tahapan bisnis yang memiliki pesaing lebih besar daripada skala bisnisnya yang tergolong ke dalam bisnis mikro tersebut.

\section{Faktor Kurangnya Motivasi}

Kurangnya motivasi menjadi seorang pedagang yang sukses dan lebih baik membuat mereka enggan untuk mengembangkan bisnisnya. Firman Allah SWT tentang motivasi terdapat pada AlQuran surat At-Taubah ayat 105:

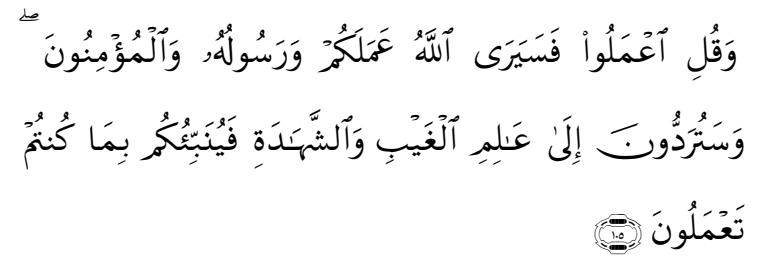

Waquli a'malu fasayara Allahu amalakum warasuluhu waalmuminuna wasaturadduna ila alimi alghaybi waashahadati fayunabbiukum bima kuntum ta'malun.

Artinya: "dan Katakanlah: "Bekerjalah kamu, Maka Allah dan Rasul-Nya serta orang-orang mukmin akan melihat pekerjaanmu itu, dan kamu akan dikembalikan kepada (Allah) yang mengetahui akan yang ghaib dan yang nyata, lalu diberitakan-Nya kepada kamu apa yang telah kamu kerjakan." (DEPAG $\mathrm{RI}, 2010)$

Beberapa pedagang muslim di Pasar Ikan Hias Gunungsari Surabaya memiliki pemikiran yang baik yang akan dilakukan pada bisnisnya, mereka memiliki motivasi yang kuat untuk merubah menjadi lebih baik. Misalnya salah seorang pedagang muslim yang saat ini dapat menjangkau konsumen yang berada di luar kota bahkan di luar pulau, dengan mengirimkan paket pesanan ikan hias kepada konsumennya. Ia mendapatkan pesanan tersebut karena kegigihannya untuk mempelajari internet dan media sosial sebagai strategi pemasaran sehingga mereka dapat menerima order/pesanan dari luar kota bahkan luar pulau. Namun masih banyak pedagang muslim yang memilih untuk berdagang seperti biasa karena tidak mengerti atau tidak ingin menggunakan strategi pemasaran melalui internet yang tentunya lebih mudah, efisien dan dapat menjangkau seluruh nusantara.

Suyana (dalam Juniar, 2013) mengatakan bahwa kurangnya dukungan pendidikan, latar belakang, pengalaman, dan kesukaan kepada suatu usaha adalah salah satu faktor yang menyebabkan wirausaha gagal, pada saat dijalankan, sehingga seseorang mundur dari usaha barunya tersebut. Kurangnya motivasi untuk merubah bisnisnya menjadi lebih baik menjadi faktor penghambat pengembangan bisnis 
juga sesuai dengan teori yang dikemukakan oleh Haryadi, et al (1998: 73).

\section{Faktor Keterbatasan Modal}

Para pedagang muslim rata-rata mengaku mengalami kesulitan dalam mendapatkan modal atau meningkatkan pendapatannya. Faktor modal sangat penting bagi perkembangan bisnis dengan skala mikro dan kecil. Pada umumnya pedagang skala mikro dan kecil merupakan usaha perorangan yang sifatnya tertutup, yang mengandalkan modal dari si pemilik yang jumlahnya sangat terbatas. Di luar modal sendiri, mereka biasanya juga mengandalkan pinjaman keluarga dekat atau tetangga untuk memenuhi kebutuhan modal.

Fakta di lapangan menunjukkan bahwa para pedagang muslim banyak yang mengalami kesulitan dalam memperoleh dana atau pendapatan. Hal ini telah disampaikan oleh beberapa pedagang muslim bahwa mereka merasa kesulitan dalam meminjam dana atau modal di koperasi milik pemerintah yang mengelola Pasar Ikan Hias Gunungsari Surabaya tersebut. Mereka mendapatkan informasi bahwa sulitnya meminjam dana dikarenakan dana yang ada pada koperasi sangat minim. Namun ada yang mengatakan bahwa untuk pedagang tertentu yang memiliki akses lebih kepada petugas koperasi dapat dengan mudah memperoleh pinjaman, hal tersebut berkebalikan dengan pedagang lain yang merasa kesulitan meminjam dana di koperasi. Keterbatasan modal merupakan salah satu faktor penghambat pengembangan bisnis sesuai dengan teori yang dikemukakan oleh Haryadi, et al (1998: 132) dan Hafsah (2004).

\section{SIMPULAN}

1. Faktor penghambat pengembangan bisnis pada pedagang muslim di Pasar Ikan Hias Gunungsari Surabaya terbentuk sebanyak tiga faktor. Faktor-faktor tersebut dinamai dengan faktor ketidaksiapan untuk bersaing, faktor kurangnya motivasi, dan faktor keterbatasan modal.

2. Indikator dengan nilai loading tertinggi yang didapat dari hasil perhitungan rotasi adalah indikator pertama $\left(X_{1}\right)$ yang terdapat pada faktor keterbatasan modal, yaitu pedagang muslim di Pasar Ikan Hias Gunungsari Surabaya tidak memiliki cukup dana yang akan digunakan dalam memenuhi kebutuhan yang diperlukan untuk dapat mengembangkan bisnisnya. Indikator yang mempunyai nilai loading tertinggi kedua adalah indikator ke-21 ( $X_{21}$ ) yang terdapat pada faktor ketidaksiapan untuk bersaing, yaitu pedagang muslim di Pasar Ikan Hias Gunungsari Surabaya tidak siap untuk bersaing dengan pesaing lainnya yang juga terlebih dahulu mengembangkan bisnisnya. Sedangkan indikator selanjutnya yang mempunyai nilai loading tertinggi terakhir adalah indikator kelima $\left(X_{5}\right)$ 
yang terdapat pada faktor

memperbanyak diskusi yang

kurangnya motivasi, yaitu pedagang

membahas

seputar

dunia

muslim di Pasar Ikan Hias Gunungsari

entrepreneur,

perkembangan

Surabaya tidak memiliki

motivasi/dorongan dalam melakukan

suatu pembaharuan menjadi lebih

baik yang akan dilakukan pada bisnisnya.

\section{Saran}

1. Bagi Pihak Pemerintah (Pengelola Pasar Ikan Hias Gunungsari Surabaya)

a. Pihak pemerintah lebih merangkul dan mengajak para pedagang untuk menyalurkan aspirasi mereka dan mewujudkannya demi keberlangsungan bisnis yang dijalankan, yaitu dengan cara melakukan pertemuan pedagang Pasar Ikan Hias Gunungsari Surabaya, khususnya pedagang muslim, yang bertujuan untuk mendiskusikan permasalahan yang menghambat para pedagang dalam mengembangkan bisnisnya dan memberikan solusi kepada para pedagang muslim. Misalnya, masalah keterbatasan modal, dengan solusi yaitu memberikan bantuan pinjaman modal usaha dengan sistem bagi hasil dan tanpa bunga (riba) yang diberikan oleh pemerintah bekerjasama dengan bank syariah serta lembaga keuangan syariah lainnya.

b. Pemerintah hendaknya memberikan bimbingan serta tuntunan dalam melakukan pengembangan bisnis, teknologi, etika bisnis Islami, dan memberikan informasi kepada seluruh pedagang muslim tentang pentingnya menjalankan zakat, infaq, dan shadaqah. Dengan begitu, pedagang tidak hanya mendapatkan bantuan secara material, tetapi juga moril.

c. Pemerintah juga harus selalu memperhatikan dan mengawasi jalannya kegiatan koperasi, serta bertindak tegas terhadap seluruh petugas dan mengevaluasi kinerja koperasi secara langsung.

2. Bagi Pedagang Muslim di Pasar Ikan Hias Gunungsari Surabaya

Diharapkan pedagang muslim bergabung dengan asosiasi atau komunitas pengusaha muslim untuk dapat saling bertukar pengalaman dan informasi yang dilakukan oleh sesama pengusaha dengan tingkat skala bisnis yang berbedabeda. Diharapkan hal tersebut akan mengubah pandangan mereka terhadap bisnis yang telah dijalankannya, sehingga dapat meningkatkan dukungan dan minat untuk mengembangkan bisnis mereka menjadi lebih baik, selain itu tentunya akan lebih memiliki persiapan dalam menghadapi pesaing yang ada karena pengalaman dan pengetahuan dari rekan sesama pengusaha.

3. Bagi Peneliti Selanjutnya 


\begin{abstract}
Penelitian ini bertujuan untuk mencari faktor penghambat yang memengaruhi pengembangan bisnis pada pedagang muslim di Pasar Ikan Hias Gunungsari Surabaya. Untuk penelitian selanjutnya, dapat diteliti faktor yang terbentuk untuk memengaruhi variabel lain, yaitu faktor pendukung yang memengaruhi pengembangan bisnis. Selain itu, pada penelitian selanjutnya, diharapkan agar cakupan subjek penelitiannya lebih luas.
\end{abstract}

\section{DAFTAR PUSTAKA}

Anshori, Muslich \& Iswati, Sri. 2009. Metodologi Penelitian Kuantitatif. Surabaya: Airlangga University Press.

Alma, Buchari. 1993. Ajaran Islam Dalam Bisnis. Bandung: Alfabeta

\& Donni Juni Priansa. 2009. Manajemen Bisnis Syariah. Bandung: Alfabeta.

Beekun, Rafiq Issa.1997. Islamic Business Ethict. Virginia: International Institute of Islamic Thought.

Bungin, Muhammad Burhan. 2005. Metode Penelitian Kuantitatif Edisi Pertama. Jakarta: Kencana.

Darmawan, Cecep, 2006. Kiat sukses Manajemen Rasulullah: Manajemen Sumber daya Insani. Jakarta: Khasanah Intelektual.

Departemen Agama RI. 2010. Al-Qur'an dan Terjemahannya. Bandung: AlMizan Publishing House.

Ghazaly, Abdul Rahman, (et al). 2012. Figh Muamalat. Jakarta: Kencana.
Hafsah, M. Jafar. 2004. Upaya Pengembangan Usaha Kecil dan Menengah (UKM).Jurnal Infokop Nomor 25 Tahun XX, 2004.

Haryadi, Dedi (et al). 1998. Tahap Perkembangan Usaha Kecil: Dinamika dan Peta Potensi Pertumbuhan. Bandung: Yayasan AKATIGA

Juniar, Rima Fauzia. 2013. Analisis Faktor yang Mempengaruhi Kurangnya Minat Berwirausaha Sarjana Muslim di Surabaya. Skripsi tidak diterbitkan. Surabaya: Fakultas Ekonomi dan Bisnis Universitas Airlangga.

Li, James Kayui. 2011. Berani Memulai dan Menjalankan Bisnis Kedai fish \& Chip dan Burger. Jakarta: Tiga Kelana.

Malhotra, Naresh K. 2010. Riset Pemasaran: Pendekatan Terapan. Jilid 2. Jakarta: PT Indeks.

Naqvi, Syed Nawab. 1993. Ethict and Economics: An Islamic Syntesis, diterjemahkan oleh Husin Anis: Etika dan IImu Ekonomi Suatu Sintesis Islami. Bandung: Mizan.

Nazir, Mohammad. 2003. Metode Penelitian. Jakarta: Ghalia Indonesia.

Poerwadarminta, W.J.S. 1976. Kamus Umum Bahasa Indonesia. Jakarta: Balai Pustaka.

Sugiyono. 2008. Metode Penelitian Kuantitatif, Kualitatif dan $R$ \& $D$. Bandung: Alfabeta.

Santoso, Singgih. 2010. Statistik Multivariat. Jakarta: PT Elex Media Komputindo. 
JESTT Vol. 2 No. 4 April 2015

Sugiyono. 2008. Metode Penelitian

http://dispendukcapil.surabaya.go.id/

Kuantitatif, Kualitatif dan $R$ \& $D$.

(diakses pada 16 Oktober 2014)

Bandung: Alfabeta.

http://wartametropolis.com/

(diakses

pada 30 Oktober 2014) 